\title{
Successful Failures of the American Constitution
}

\author{
James E. Fleming \\ Conference on "The Limits of Constitutional Democracy" \\ Princeton University, February 14-16, 2007
}

I. Introduction

A. It is an honor and a pleasure to be here to celebrate the publication of Walter F. Murphy's magnum opus - Constitutional Democracy: Creating and Maintaining a Just Political Order - by analyzing "The Limits of Constitutional Democracy."

1. Walter's book is an awesome work: any careful reader will be awed by its learning.

2. And it bristles with practical and theoretical wisdom, well deserving the name jurisprudence.

B. I want to make three observations about the richly suggestive ambiguity in the title of the conference. Let's parse it: "The Limits of Constitutional Democracy."

C. First, "Constitutional Democracy," Walter's signature formulation and the apt title of his book.

1. Walter argues that the American constitutional order is a constitutional democracy - a hybrid of constitutionalism and democracy - rather than a majoritarian representative democracy.

2. This formulation set me - and a whole generation of his graduate students at Princeton - down the right path.

3. For it enabled us to avoid the confused and fruitless fretting about judicial review posing a "counter-majoritarian difficulty" or being a "deviant institution" that has disfigured so much constitutional scholarship, especially that by law professors.

4. Indeed, I recently published a book whose title - Securing Constitutional Democracy: The Case of Autonomy - pays tribute to Walter's analysis.

5. Thank you, Walter, for your clear-headed and wise conceptualization of constitutional democracy. 


\section{Fleming, Constitutional Failure, p. 2}

D. Second, "Limits."

1. Walter emphasizes constitutions and constitutionalism as placing limits on political power and majority will.

a. But he also sees the limitations of viewing constitutions and constitutionalism as merely negative.

b. He recognizes that constitutions establish and empower governments, and may impose affirmative obligations upon government to pursue certain goods or ends (e.g., affirmative constitutionalism).

2. Walter also conceives deeper limits of constitutional democracy than are commonly acknowledged or accepted.

a. I am speaking of his signature idea that there are limits to legitimate constitutional change and indeed that certain purported amendments to a constitution may be unconstitutional on the ground that they flout those limits.

b. I'll say more about this later.

E. But third, "limits" can also connote "limitations," as in the shortcomings of constitutional democracy.

1. For example, the very limits safeguarding individual freedoms celebrated by civil libertarians are viewed by some as placing limitations on our constitutional democracy's ability effectively to face certain challenges, such as those of waging a permanent "war on terror."

2. More generally, some view the limits our Constitution imposes as making effective, responsible government more difficult if not impossible to attain.

F. Those of you who know my work may ask, what am I doing on a panel on constitutional failure?

1. After all, in my book, Securing Constitutional Democracy, I put forward a "Constitution-perfecting theory," a theory that strives to interpret the American Constitution so as to make it the best it can be.

2. And I have been accused of subscribing to the "perfect Constitution" view that Henry Monaghan famously derided (and that Chris Eisgruber has cleverly analyzed). 


\section{Fleming, Constitutional Failure, p. 3}

3. That might make me seem an unlikely candidate for a panel on constitutional failure.

4. But there is no inconsistency between propounding a Constitution-perfecting theory and believing that the American Constitution as it stands is seriously flawed.

5. For a Constitution-perfecting theory does not entail that the Constitution is the best a constitution can be.

6. Rather, it entails that, in interpreting whatever imperfect constitution we have, we should strive to make it the best it can be.

II. What is Constitutional Failure?

A. I want to pose a number of questions about constitutional failure without claiming to answer them.

B. What is constitutional failure? Does it presuppose a conception of constitutional success, and of the preconditions for constitutional success (as Sot has argued)?

C. How does a constitutional failure differ from or relate to other constitutional misfortunes, such as a crisis? A tragedy? A stupidity? An evil? An imperfection?

1. Sandy Levinson, Mark Graber, and John Finn, among others, have insightfully analyzed these other sorts of misfortune.

D. Furthermore, how does a constitutional failure differ from or relate to other types of failure, such as a moral failure? A political failure? An institutional failure? A failure of policy?

E. However we answer these questions, it seems clear that we have no dearth of constitutional misfortunes. Without purporting to answer these questions, I shall:

1. make some observations about the discourse of failure that is in the air at the present time;

2. examine the implications of Walter's book and Sandy Levinson's recent book for constitutional failure; and

3. discuss a phenomenon I'll call successful failures of the American Constitution. 


\section{Fleming, Constitutional Failure, p. 4}

III. Discourse of Failure in the Air

A. Whatever failure is, there is considerable talk of it in the air these days.

1. Just consider these titles:

a. Bruce Ackerman's The Failure of the Founding Fathers: Jefferson, Marshall, and the Rise of Presidential Democracy;

b. Ronald Dworkin's Is Democracy Possible Here?: Principles for a New Political Debate;

c. $\quad$ Alan Wolfe's Does American Democracy Still Work?;

d. and Sandy Levinson's Our Undemocratic Constitution: Where the Constitution Goes Wrong (and How We the People Can Correct It).

2. Consider also:

a. John Dean's Broken Government: How Republican Rule Destroyed the Legislative, Executive, and Judicial Branches;

b. Thomas Mann \& Norman Ornstein's The Broken Branch: How Congress is Failing America and How to Get It Back on Track;

c. and Robert Kuttner's The Squandering of America: How the Failure of Our Politics Undermines Our Prosperity.

3. Before this recent spate of books, there was:

a. Mark Brandon's Free in the World: American Slavery and Constitutional Failure;

b. John Finn's Constitutions in Crisis: Political Violence and the Rule of Law;

c. and Ellen Kennedy's Constitutional Failure: Carl Schmitt in Weimar.

d. I should also mention Will Harris's The Interpretable Constitution and Sot Barber's On What the Constitution Means, for both of these works - though they don't cry out "failure" in their titles - prefigure our discussion of constitutional failure in this conference. 


\section{Fleming, Constitutional Failure, p. 5}

4. Doubtless there are other examples as well, but this list should serve to illustrate the range of discourse about failure.

B. Mark Brandon has offered a useful typology of constitutional failure, distinguishing four distinct types or domains of failure:

1. A failure of constitutionalism

2. A failure of a constitution

3. A failure of constitutional order

4. A failure of constitutional discourse

5. Brandon strikingly observes that success in one domain can contribute to failure in another, and vice versa.

6. I would add that we might even conceive of successful failures: features of a constitution that fail to work as contemplated when designed but nonetheless work tolerably well and in that sense are successful. I'll say more about this below.

C. We might try to map the foregoing books onto Brandon's typology and see whether any of these authors really is diagnosing constitutional failure.

D. Or, we might ask, is anyone really arguing that we are experiencing a constitutional failure, as distinguished from a moral failure, a political failure, an institutional failure, or a failure of policy that may or may not be directly related to the Constitution?

1. The striking fact of the matter is that, for all the ominous talk of failure, it is for the most part not talk of constitutional failure.

2. Instead, it is talk of other sorts of shortcomings or failure.

3. It appears that the worrisome states of affairs diagnosed are not directly attributable to the Constitution.

a. Of course, it could be the case that these types of failure, though not themselves constitutional failure, are ultimately attributable to the Constitution in the sense that they are made more likely by our constitutional design. 


\section{Fleming, Constitutional Failure, p. 6}

b. This seems to be the suggestion of Sot's critique of Madison's (and our Constitution's) of eschewal of the Aristotelian tradition of "supplying the defect of better motives" by inculcating moral and civic virtues in favor of a strategy of private incentives.

4. I'm going to focus on the implications of Sandy's book, Our Undemocratic Constitution, and Walter's book, Constitutional Democracy, for constitutional failure.

IV. Sandy Levinson's Our Undemocratic Constitution: Where the Constitution Goes Wrong (and How We the People Can Correct It): A Constitutional Failure or Simply an Undemocratic Constitution?

A. I think Sandy's book is the closest thing we have in mainstream constitutional scholarship to an argument that the American Constitution has failed or is in serious danger of failing.

1. Sandy, however, is really talking not about failure but about serious defects, problematic dysfunction, and "hard-wired features" of our structural Constitution that could contribute to a crisis if not a failure.

2. Nowhere does he say our Constitution has failed.

3. Indeed, much of his beef with the Constitution and our constitutional culture concerns the extent to which we venerate the Constitution and view it as having been so successful.

a. Thus, he laments that it is so difficult to get people aroused about the need for a constitutional convention to make basic changes in the structural Constitution.

b. He is frustrated that it is such a huge struggle to get people to see, as he puts it, where the Constitution goes wrong.

c. It's even more difficult to get them motivated to press for a constitutional convention to correct it.

B. What exactly is Sandy's indictment of the American Constitution?

1. He argues that it is seriously undemocratic as measured by a normative theory of democracy that is more majoritarian than the arrangements established in the Constitution. 


\section{Fleming, Constitutional Failure, p. 7}

2. His criticism also includes a number of empirical propositions in support of the view that the constitutional order is dysfunctional, if not broken.

a. Sandy told me in an email that he had proposed to Oxford University Press the title of "Our Broken Constitution," but they declined because they had already used "broken" in the title of the MannOrnstein book, The Broken Branch: How Congress is Failing America and How to Get It Back on Track.

(1) Mann \& Ornstein diagnose the institutional failure of Congress.

(2) For what it is worth, I think it's a good thing that Oxford didn't let Sandy use that title, because it would not have fit his book as well as the title they agreed upon does.

3. To be sure, Sandy fears that the undemocratic features of our structural Constitution he criticizes may contribute to constitutional crises, and he tells us about a number of crises that we have narrowly averted (some of which we didn't even know about).

a. E.g., in 1976, had only 5,559 voters in Ohio and 3,687 voters in Hawaii voted for Gerald Ford instead of Jimmy Carter, Ford would have had 269 electoral votes to Carter's 268 and Reagan's 1, and that would have sent the choice to the House of Representatives. (94)

4. But his analysis, focusing as it does on the "hard wired features" of our structural Constitution that have been in place since the beginning, could have been written at most any time during the nation's history, and certainly any time during the $20^{\text {th }}$ Century.

a. Granted, the presidential election controversy culminating in Bush v. Gore, shifts in population resulting in the disproportionate influence of small states in the Senate and the Electoral College, and the emergence of the red states-blue states phenomenon (with small red states having disproportionate influence in presidential elections) give the book a special urgency at the present time.

b. Nonetheless, even if George Bush had easily carried Florida in the 2000 presidential election and Al Gore had conceded defeat on election night, Sandy still would have viewed the outcome as a travesty that demonstrates one importance place where the Constitution goes wrong (and what We the People should do to 


\section{Fleming, Constitutional Failure, p. 8}

correct it). After all, Gore still would have won the nationwide popular vote by a considerable margin and still would have lost in the Electoral College, 271-267.

c. And so, Sandy still would have called for the abolition or reform of the Electoral College.

5. Thus, Sandy's book is not simply a diagnosis of constitutional failure at the present time.

6. Instead, it is a descendant of writing during the progressive era castigating the Constitution for being undemocratic and for not embodying a British-style system of parliamentary supremacy.

a. Not surprisingly, Sandy praises this progressive era literature and the progressive movement for constitutional change.

7. Woodrow Wilson could have written much of this book (indeed witness the quotation from Wilson with which Sandy concludes his book).

8. And Sandy's old nemesis, Felix Frankfurter, surely would have approved of it.

9. So would most any progressive Anglophile.

10. I interpret Sandy's book as a democratic manifesto whose opening line could be: "Anglophiles of the United States, Unite! You have nothing to lose but your undemocratic chains (or "iron cage," the term he repeatedly invokes)!"

11. I'll come back to Sandy's analysis later.

V. Walter Murphy's Constitutional Democracy: Creating and Maintaining a Just Constitutional Order: Creation, Maintenance, and Change as Possible Sites of Constitutional Failure

A. In Constitutional Democracy, Walter does not develop a theory of constitutional failure as such.

1. Instead, he focuses on constitutional creation, maintenance, and change.

2. Nonetheless, we can infer from his analysis three principal possible sites of constitutional failure, to wit: (1) creation; (2) maintenance; and (3) change.

B. First, a constitution or constitutional order might fail in its very creation. 


\section{Fleming, Constitutional Failure, p. 9}

1. Cf. a botched design.

2. It might prove to be wholly inadequate to pursuing its ends.

3. The Articles of Confederation, Sot points out, failed in this way, even if it was not a total constitutional failure.

4. We the People, after all, proved capable of constitutional reform, of forming "a more perfect union" through adopting the Constitution.

C. Second, a constitution or constitutional order might fail due to improper or inadequate maintenance.

1. Here, a striking implication of Walter's analysis of constitutional interpretation as constitutional maintenance is that a constitutional order would likely fail (due to poor maintenance) if it were to follow a narrow originalism.

a. This claim should get my fellow panelist Keith Whittington's attention!

2. Below I'll ponder Walter's analysis in this respect.

D. Third, a constitution or constitutional order might fail with respect to change or reform. I'll distinguish two types of such failure.

1. One, a people might lose the very capacity to change or reform.

a. Walter and Sot clearly would view this as a form of failure.

b. There may be implicit in Sandy's criticism of our undemocratic Constitution, in particular, Article V's onerous procedures for amendment, the charge that it has enervated or destroyed our very capacity to change or reform through constitutional amendment.

2. Two, a constitution or constitutional order might breach the limits of legitimate constitutional change, for example, by adopting what Walter would conceive as an unconstitutional amendment.

a. That, too, would be a form of failure or breakdown.

b. I should also mention Will Harris's rich and subtle analysis of the 


\section{Fleming, Constitutional Failure, p. 10}

limits of textual amendability (in his The Interpretable Constitution).

3. Walter famously distinguishes between amending a constitutional order (correcting, adjusting, or modifying it) and repudiating it (destroying it and creating another one).

a. He argues that purported amendments that do the latter exceed the limits of legitimate constitutional change.

b. He even argues that such purported constitutional amendments are unconstitutional.

c. Such amendments would signal a repudiation or breakdown of the existing regime or a change of identity to a new regime - by destroying an existing constitutional order and creating another one.

4. Years ago, in a conference here at Princeton on the occasion of Walter's retirement, I considered whether Bruce Ackerman's two hypothetical Christianity amendments discussed in his We the People: Foundations - the first establishing Christianity as the state religion of the American people and the second forbidding repeal of the first - might be such unconstitutional amendments. I'll not repeat that analysis here.

E. Now, I am going to ask whether any of the amendments Sandy hopes for would amount to (what Walter would view as) an unconstitutional constitutional amendment.

1. I am assuming that we would not have a constitutional convention (contrary to Sandy's hopes), but that we nonetheless would adopt several amendments he would support to eliminate or mitigate the undemocratic features of the Constitution he condemns.

2. For example, we might abolish the Electoral College in favor of direct popular election of the President.

3. And we might amend Article $\mathrm{V}$ to eliminate the role of the states in amending the Constitution and to make it easier for the people to amend it, e.g., in favor of requiring proposal by $60 \%$ of the federal legislators and ratification by $60 \%$ of the voters in a national referendum.

a. (You will notice that I chose $60 \%$, to make the process more onerous than requiring only a simple majority but less burdensome than requiring the present proposal by $2 / 3$ of both houses of Congress and 


\section{Fleming, Constitutional Failure, p. 11}

ratification by $3 / 4$ of the states.)

4. We might even abolish the Senate in favor of unicameralism.

a. (Article V does say that "no state, without its consent, shall be deprived of its equal suffrage in the Senate," but it does not say that we have to have a Senate.)

5. We could come up with many other changes to the "hard-wired features" of the structural Constitution that Sandy might support.

F. Would any of these amendments go beyond the limits of legitimate constitutional change and thus be unconstitutional amendments in Walter's sense?

1. I think not.

2. None of them would be incompatible with, much less destroy, our scheme of constitutional democracy as Walter conceives it.

3. To be sure, some of the changes would make the Constitution more of what Walter calls a majoritarian "representative democracy" as distinguished from a "constitutional democracy."

4. But such changes would not move us so far on Walter's continuum from constitutionalism to democracy as to make it appear that we had alienated our "unalienable" rights or repudiated our basic principles, that is, renounced principles that are the essence of our constitutional democracy.

5. This should come as no surprise, since Sandy's concern is with changing certain "hard-wired details" of our structural Constitution, not with repudiating fundamental rights protecting the dignity, liberty, or equality of individuals or groups.

6. The latter are what we more commonly think of as "unalienable rights" or fundamental, constitutive principles of our constitutional democracy.

7. Repudiating them might rise to the level of what Walter would call unconstitutional amendments because they might repudiate the constitutional order.

VI. Constitutional Interpretation as Constitutional Maintenance: Or, the Possibility of Failure through Inadequate Maintenance 


\section{Fleming, Constitutional Failure, p. 12}

A. Finally, I want to return to the second site of possible failure mentioned above - the idea, implicit in Walter's analysis, that a constitution or constitutional order might fail through inadequate maintenance.

B. In American Constitutional Interpretation, Walter along with his humble co-authors conceive the enterprise of constitutional interpretation on the basis of three fundamental interrogatives: (1) What is the Constitution?; (2) Who may authoritatively interpret it?; and (3) How ought it to be interpreted?

C. Walter's idea of constitutional interpretation as constitutional maintenance fosters a more comprehensive and comprehending view of all three interrogatives - What, Who, and How? - than do conventional accounts of constitutional interpretation, especially originalist accounts.

1. What is the Constitution? On Walter's view, the Constitution includes not only the constitutional document but also the broader constitutional order: original understanding, underlying political theories of democracy and constitutionalism, previous interpretations, settled practices, traditions, and aspirations. Furthermore, the constitutional document and constitutional order encompass purposes such as those set forth in the preamble.

2. Who may interpret? Instead of judicial monopoly, Walter embraces departmentalism, that is, dividing interpretive authority among courts, legislatures, and executives.

3. How to interpret? Not "clause-bound interpretivism" or narrow originalism, but the reasoned judgment of constitutional statesmanship.

4. I want to make three points about Walter's analysis of constitutional maintenance in relation to the idea of constitutional failure.

D. My first point concerns Walter's important and insightful emphasis upon the idea of maintenance itself: it underscores that the Constitution is not "a machine that would go of itself."

1. Instead, it is a scheme that requires maintenance and repair to make it work, to keep it from failing.

2. To be sure, Walter's departmentalism is hospitable to the view that constitutional norms are self-enforcing through the operation of the political processes to a greater degree than is acknowledged by conventional courtcentered accounts. 


\section{Fleming, Constitutional Failure, p. 13}

a. Such accounts mistakenly think that the only protection of constitutional norms comes from courts enforcing them against the political processes.

3. But Walter's account emphasizes the place of courts in the larger institutional scheme of courts, legislatures, and executives sharing authority and responsibility to interpret the Constitution so as to maintain the system.

4. Furthermore, Walter's idea of maintenance is more comprehensive and comprehending than interpretation conceived in narrow originalist fashion as doing backward-looking historical research into relatively concrete original meanings and then preserving those meanings against encroachment or change.

E. The second point stems from the fact, already noted, that Walter's idea of constitutional interpretation as constitutional maintenance encourages a broader (more comprehensive and comprehending) view of What and How than do conventional accounts, in particular, originalist accounts.

1. It fosters a salutary concern for furthering the purposes of the constitutional order instead of being focused in a backward-looking way with interpreting narrowly conceived clauses in isolation or with taking a litigation-oriented perspective.

2. Now, one of the great things about Walter's work is that it is (as I would put it) proudly "post-originalist."

a. Originalists in the U.S.A. piously proclaim that interpretation necessarily entails originalism. Or that interpreters should "try to return to the founding -...to think the thoughts founders were thinking." (P.

b. Walter's exercise in comparative constitutional law exposes their provincialism: he powerfully retorts that this view is "pretty much restricted to the United States." (

3. Originalists typically claim that they have a monopoly on the classical, interpretive justification of judicial review: courts are to interpret the Constitution and to preserve it against encroachment by legislative and executive encroachment.

4. Originalists might say that they, too, believe in constitutional maintenance in this sense of preservation. 
a. For example, Scalia likes to say that the point of the Constitution is to preserve the original meaning of the Constitution and to prevent change.

b. Indeed, he has written that the Constitution's "whole purpose is to prevent change."

c. According to Scalia, "A society that adopts a bill of rights is skeptical that 'evolving standards of decency' always 'mark progress,' and that societies always 'mature,' as opposed to rot."

d. For a society or a constitution to "rot" sounds like a form of failure.

5. But Walter's analysis implies that narrow originalism, if scrupulously practiced, would be a poor form of constitutional maintenance.

6. He might even suggest that, thankfully for the sake of maintenance, originalism is honored more in the breach than in the observance.

F. The third point concerns the fact that Walter's idea of constitutional interpretation as constitutional maintenance fosters a broader (more comprehensive and comprehending) view of Who than do conventional accounts.

1. It fosters a healthy, vigorous departmentalism, as opposed to conventional accounts of judicial monopoly or at least judicial supremacy, especially the hubristic view of the Rehnquist Court (and possibly the Roberts Court).

2. Walter wisely observes that despite the claims of judicial monopoly or judicial supremacy, the actual practice of most arrangements in fact produces some form of departmentalism.

3. He also wisely argues that some form of departmentalism is healthier than having courts be the ultimate if not the exclusive interpreter:

4. Walter prudently situates interpreters as political actors in the political system, and he presents interpretation as part of the operation of the political system, not simply as the peculiar province of judges divining the meaning of a legal document.

5. His conception of constitutional maintenance at once broadens what courts' constitutional responsibilities are and broadens what legislative and executive responsibilities are. 


\section{Fleming, Constitutional Failure, p. 15}

6. Legislatures and executives share in both the responsibility of interpretation and of maintenance.

7. Under such a departmentalist arrangement, a constitutional order may be more successful at constitutional maintenance that staves off decline, breakdown, and failure than under a system of judicial monopoly that ignores the imperatives of constitutional statesmanship and drives out the idea of taking the Constitution seriously outside the courts.

\section{Successful Failures of the American Constitution}

A. Again, Sot points out that any theory of constitutional failure presupposes a conception of constitutional success and of the preconditions for constitutional success.

B. We should also recognize the possibility of successful failures.

1. Sometimes, features of a constitution or constitutional order fail to work as designed or contemplated, but that failure turns out to be a good thing.

2. For things work differently than contemplated, but they still work tolerably well or even better, all things considered, than they would have if they had worked as contemplated.

C. Let me mention several examples of such successful failures.

1. First, the successful failure of the strategy of enumerated federal powers.

a. Let's assume for the sake of argument - with the antifederalists and the Federalist Society today - that the original Constitution's strategy was to conform rigidly to a principle of limited and enumerated federal powers.

b. It is a good thing that, beginning at least with McCulloch v. Maryland (1819), we have not rigidly followed such a principle.

c. For our federal government surely would be inadequate to pursuing the Constitution's ends under such a scheme.

d. Even though the Rehnquist Court to some extent tried to revive this strategy, its federalism counter-revolution seems to have been largely symbolic and seems to have retreated somewhat in the end. 
e. And 9/11 and Hurricane Katrina demonstrated even to "new federalism" republicans the need for a strong federal government with powers not specifically enumerated in the Constitution.

2. Second, the successful failure of the strategy of enumerated constitutional rights.

a. Let's assume for the sake of argument - with the narrow originalists - that the original Constitution's strategy was to enumerate all the constitutional rights we have and (contrary to the implication of the Ninth Amendment) to exclude the protection of rights not enumerated in the text.

b. It is a good thing that we have not followed such a principle.

c. For our Constitution and constitutional law would be far less protective of our basic liberties, and far less worthy of our affirmation and support, under such an arrangement.

3. Third, and relatedly, the successful failure of originalism to limit constitutional interpretation to enforcing the relatively specific original understandings of the framers and ratifiers.

a. Let's assume for the sake of argument that there was an original understanding (or design) that the Constitution should be interpreted according to the principles of narrow originalism.

b. It is a good thing that in practice courts have eschewed such a programmatic originalism in favor of what Sot and I have called a fusion of approaches to constitutional interpretation (in our recent book, Constitutional Interpretation: The Basic Questions) and what Walter has called constitutional interpretation as constitutional maintenance (discussed above).

4. Fourth, the successful failure of the Electoral College.

a. Disclaimer: I hasten to say that Sandy puts forward a powerful critique of the Electoral College, and that I would support a constitutional amendment to abolish it or at least to alter it to a system of proportional allocation of each state's electoral votes instead of the largely winner-take-all system we currently have. 


\section{Fleming, Constitutional Failure, p. 17}

b. In speaking of the successful failure of the Electoral College, I refer to the failure of the Electoral College to work as might have been contemplated: with electors of each state, exercising independent judgment, really choosing the President (without being bound by the popular vote of the state).

c. Instead, as things have turned out, the electors largely ratify the choice of the state-wide electorate. That is a more defensible state of affairs than contemplated.

d. And so, I would say that though the Electoral College is imperfect, it has worked tolerably well on the whole.

e. Let us remember that the problems of the presidential election controversy leading up to Bush v. Gore were not in the first instance problems of the Electoral College; instead they were problems of the Florida voting system, with its variety of voting machines from county to county and all the rest of it.

5. Finally, the successful failure of the founding fathers to anticipate the rise of parties and the rise of presidential democracy (here of course I allude to Bruce Ackerman's recent book).

D. My examples of successful failures show that, to some extent, one persons's success is another's failure, and vice versa (or, success from one theoretical standpoint is failure from another).

1. We can also see this phenomenon in the First Things symposium some years ago in which conservatives lamented the "end of democracy" through Supreme Court decisions like Planned Parenthood v. Casey and Romer v. Evans,

2. at the same time that many liberals celebrated these same decisions as confirming the status of equal citizenship of women and gays and lesbians in our constitutional democracy.

VIII. Conclusion

A. By no means do we have adequate accounts of constitutional failure and success.

B. But Walter's and Sandy's books certainly help to illuminate the questions to be considered and the possible sites of failure to be analyzed. 